\title{
Evaluation of polypropylene degradation with commercial additives in different media of exposure
}

\author{
Avaliação da degradação de polipropileno com aditivos comerciais em \\ diferentes meios de exposição
}

\author{
Jéssica Pereira Pires' \\ Alessandro da Silva Ramos" \\ Gabriela Messias Miranda"I \\ Rosane Angélica Ligabue ${ }^{\mathrm{IV}}$ \\ Jeane Ayres de Limav \\ Rogério Vescia Lourega ${ }^{\mathrm{VI}}$
}

\begin{abstract}
Polypropylene (PP) is one of the most widely used polymers in the world, mainly due to its versatility, good properties, and low cost. However, since it is not easily degraded in the natural environment, several research projects have been developed to increase its biodegradability. The use of pro-degrading additives has been explored, as they promote the process of polymer degradation. Nevertheless, few studies have evaluated the degradation of these materials in natural aqueous environments such as rivers and lakes, which contain large amounts of PP waste. The goal of this study was to evaluate the degradation of polypropylene, as well as the biodegradation of PP through the incorporation of two additives of different natures, organic and enzymatic. For this purpose, PP blends were produced with $4 \%$ additive, which has the purpose of conferring biodegradability to the material, since polypropylene has high resistance to degradation. In order to verify the behavior of the materials against degradation tests with 2 different media (saline and fresh water) for a period of 6 months, the samples were characterized by Fourier Transformed Infrared Spectroscopy and Field emission scanning electron microscopy. The characterizations were carried out in order to verify the changes in the structural characteristics and in the morphology of the materials caused by the incorporation of the additive and by the exposure to the degradation media. From the results obtained, it was observed that the additives influenced the degradation of PP. In addition, the enzyme additive and the saline media caused more significant changes in the properties analyzed, indicating greater influence on the degradation process. It was concluded that the incorporation of commercial additives gives biodegradable properties to PP. Therefore, this study has an important role in the research and development of biodegradable materials in order to minimize the effects caused by plastic waste in the environment. Thus, the studied materials are an alternative in the field of plastic packaging, reducing the effects caused by plastic waste in the environment.
\end{abstract}

Keywords: Polypropylene; Additives; Degradation media.

\footnotetext{
'Pontifícia Universidade Católica do Rio Grande do Sul (PUCRS), Porto Alegre, RS, Brazil - jessica.pires.001@acad.pucrs.br. "Pontifícia Universidade Católica do Rio Grande do Sul (PUCRS), Porto Alegre, RS, Brazil - alessandro.ramos@acad.pucrs.br. III Pontifícia Universidade Católica do Rio Grande do Sul (PUCRS), Porto Alegre, RS, Brazil - gabriela.messias@edu.pucrs.br.

IV Pontifícia Universidade Católica do Rio Grande do Sul (PUCRS), Porto Alegre, RS, Brazil - rligabue@pucrs.br..

v Pontifícia Universidade Católica do Rio Grande do Sul (PUCRS), Porto Alegre, RS, Brazil - jeane.lima@pucrs.br.

${ }^{\mathrm{V}}$ Company INPROS. Porto Alegre, RS, Brazil - louregarv@gmail.com.
} 


\section{Resumo}

O polipropileno (PP) é um dos polímeros mais amplamente utilizados no mundo, principalmente devido à sua versatilidade, boas propriedades e baixo custo. No entanto, como não se degrada facilmente no ambiente natural, vários projetos de pesquisa foram desenvolvidos para aumentar sua biodegradabilidade. $\mathrm{O}$ uso de aditivos pró-degradantes tem sido explorado, pois promovem o processo de degradação de polímeros. No entanto, poucos estudos avaliaram a degradação desses materiais em ambientes aquosos naturais, como rios e lagos, que contêm grandes quantidades de resíduos de PP. O objetivo deste trabalho é avaliar a degradação do polipropileno, bem como a biodegradação do PP através da incorporação de dois aditivos de naturezas distintas, orgânica e enzimática. Para este fim, foram produzidas blendas de PP com 4\% de aditivo, os quais tem a finalidade de conferir biodegradabilidade ao material, visto que o polipropileno apresenta alta resistência à degradação. No intuito de verificar o comportamento dos materiais frente a ensaios de degradação com 2 diferentes meios (água salina e água doce), por um período de 6 meses, as amostras foram caracterizadas por Espectroscopia de Infravermelho com Transformada de Fourier e por Microscopia Eletrônica de Varredura com Emissão de Campo. As caracterizações foram realizadas com o intuito de verificar as alterações nas características estruturais e na morfologia dos materiais provocadas pela incorporação do aditivo e pela exposição aos meios de degradação. A partir dos resultados obtidos foi observado que os aditivos influenciaram na degradação do PP. Além disso, o aditivo enzimático e o meio salino provocaram alterações mais expressivas nas propriedades analisadas, indicando maior influência sobre o processo de degradação. Concluiu-se que a incorporação dos aditivos comerciais atribui ao PP propriedades biodegradantes. Desta forma, este trabalho possui um importante papel na pesquisa e desenvolvimento de matérias biodegradáveis com o objetivo de minimizar os efeitos causados pelos resíduos plásticos no meio ambiente. Assim, os materiais estudados são uma alternativa no campo das embalagens plásticas, reduzindo os efeitos causados pelos resíduos plásticos no meio ambiente.

Palavras-chave: Polipropileno; Aditivos; Meios de degradação. 


\section{Introduction}

The materials usually known as plastics experienced, throughout the second half of the 20th century, a spectacular evolution both in the properties and characteristics that they present and in the countless applications that they have in daily life. As a consequence, increasing quantities of these materials are being produced and put into circulation, a trend that should prevail in the coming years. Perhaps more than any other material, plastic is associated with the idea of technological advancement and " modernity " (Piatti and Rodrigues, 2005; Zanin, 2015).

There are different types of plastics depending on the length of the chain, the structure of the polymer, among other aspects. According to the Brazilian Association of the Plastics Industry (ABIPLAST), the most consumed polymers today are: Polyethylene Terephthalate (PET); High density polyethylene (HDPE); Polyvinyl Chloride (PVC); Low density polyethylene (LDPE); Polypropylene (PP); Polystyrene (PS); Acrylonitrile Butadiene Styrene (ABS); Acrylonitrile Styrene (SAN), and Satin Vinyl Foam (SVF). In addition to those mentioned, Polyamides (PA), Polycarbonates (PC), Polyurethanes (PU), and Polytetrafluoroethylene (PTFE) are produced on a smaller scale due to their high cost and specific applications (Abiplast, 2016). In addition, thermoplastic resins are the most used in manufacturing industries due to their good processability and versatility (Abiplast, 2015).

Plastics provide benefits to society such as: ease of transport and production, energy savings, and production of a variety of materials. This is mainly due to its versatility and diversity, but also to other properties such as: low density, durability, and low cost (Miyazaki et al., 2012). Moreover, due to the advantages presented, plastic has been substituting other materials such as metals, glass, paper, among others. As a result, world production of plastics has increased strongly, from 1.7 million tons in 1950 to 348 million tons in 2017 (Plastic Europe, 2018). In Brazil, the consumption of thermoplastic resins per individual in 2017 was estimated at $29 \mathrm{~kg}$ per inhabitant against $28 \mathrm{~kg}$ in 2016 (Abre, 2018).

Although they represent a much more noble use of oil than simply burning it as fuel, the use of plastic materials does not only bring benefits (Zanin, 2015). These materials have accumulated in the environment as a result of their structural stability that gives them a 
high resistance to degradation (Ojeda, 2008). At the same time, another factor that contributes to the accumulation of plastic waste is its incorrect disposal, causing other problems such as visual pollution, impediment of rainfall runoff on urban roads, pollution of rivers and seas, choking of animals, among others.

It should also be noted that many of these materials could still be reused or recycled before disposal, but these are alternatives with practical limitations. As a result, there are alternatives for the treatment of this waste, such as disposal in landfills and incineration. However, the disposal of this waste in landfills is not indicated because they occupy a large space, as well as incineration is not the most suitable alternative due to pollutant emissions (such as dioxins, furans, particulate matter, polycyclic aromatic hydrocarbons, among others) during burning, the disposal of ash from the burning, and the lack of technology available in the country. Thus, an alternative to alleviate the problems caused by plastic waste in the environment is the research and search for something that favors the degradation or biodegradation of these polymers (Achilias et al., 2007; Lazarevic et al., 2010; Faria and Martins-Franchetti, 2010).

Commercial biodegradable polymers like Polylactic acid (PLA), Polyhydroxybutyrate $(\mathrm{PHB})$, Polycaprolactone $(\mathrm{PCL})$, among others, can be an alternative to minimize the effects of discarding these materials even though they have properties that restrict their use, in addition to being more expensive than conventional plastics (Ojeda, 2008). Another alternative that has been explored is degradable polyolefin, which can be obtained with the addition of special additives called pro-oxidants.

These additives catalyze the breakdown of bonds through heat or light accelerating abiotic oxidation and increasing the degradability of polymers (Rosa et al., 2000; Liu et al., 2014). Most additives are composed of transition metals, which can cause damage to the environment due to their toxicological potential (Fontanella et al., 2013). According to Thomas et al. (2012), the biodegradation of oxidizable plastics occurs after their fragmentation, but the fact that these plastic fragments remain in the environment causes a great concern with their ingestion by insects, birds, fish, and other animals. 
Therefore, considering the importance of research that evaluates the influence of additives on the degradation of polyolefins in order to minimize the effects caused by plastic waste, and at the same time aiming to preserve the plastic properties, this research targets to evaluate the biodegradation of PP through the incorporation of two distinct additives of different nature (organic and enzymatic). These evaluations were carried out in order to compare the results obtained for the degradation of a common plastic versus a plastic added in two degradation media: fresh water and saline water.

\section{Materials and methods}

Figure 1 presents the methodology schema used for this study. The steps described will be discussed in the following sections.

Figure 1 - Methodology schema used in this study.

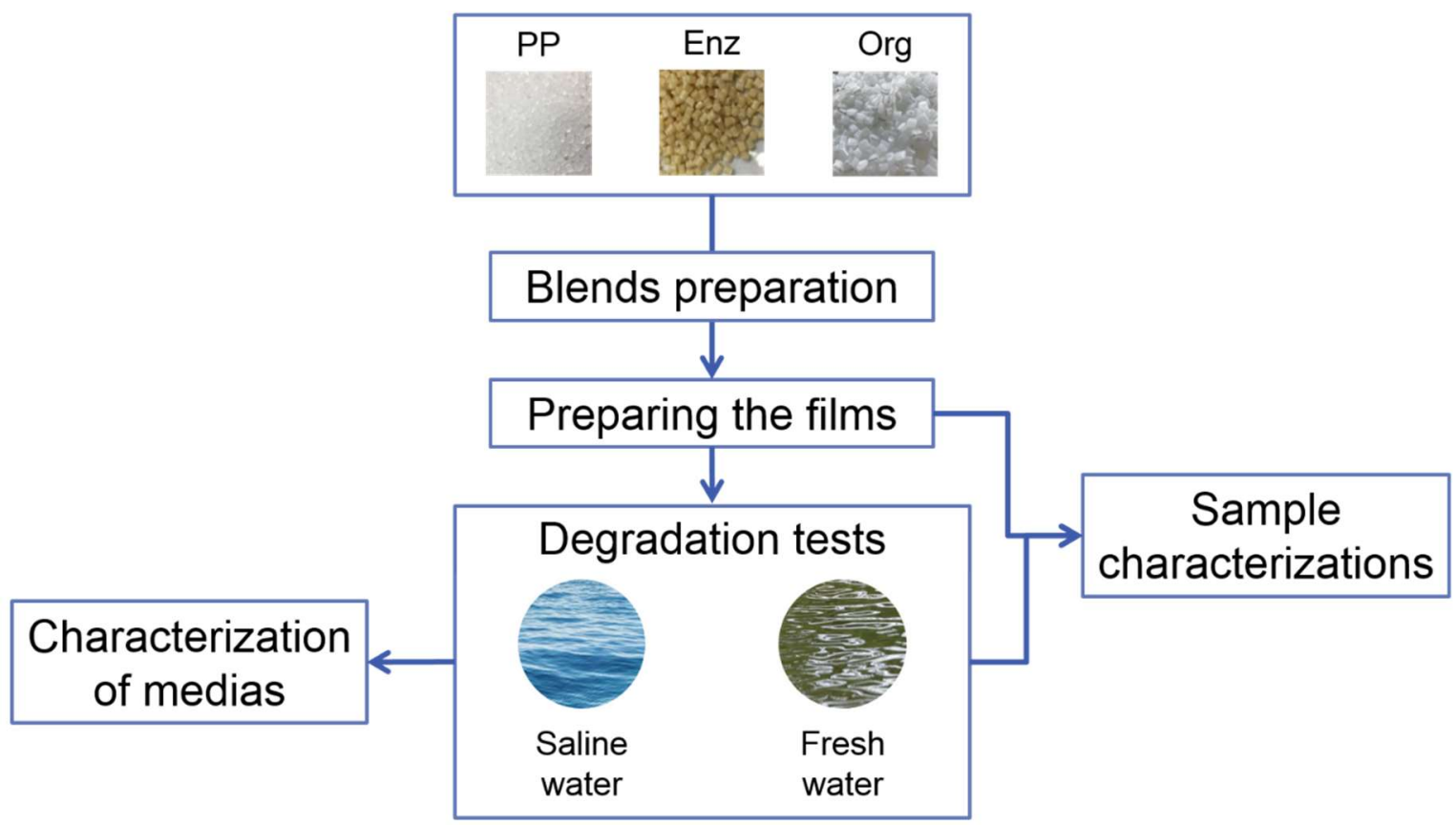

\subsection{Materials}

The materials used for making the blends are described in Table 1. 
Chart 1 - Materials used

\begin{tabular}{|c|c|}
\hline Material & Characteristics \\
\hline Polypropylene & Type: Isotactic. Density: $0.9 \mathrm{~g} / \mathrm{cm}^{3}$ \\
\hline Enzyme & Formed by $95 \%$ LLDPE and $5 \%$ enzymatic \\
Additive & compound. \\
\hline Organic & Formed by $50 \%$ PP and $50 \%$ organic \\
Additive & compounds. \\
\hline
\end{tabular}

The degradation experiments were carried out in two different media (fresh water and sea water) whose parameters were described in Table 1.

Table 1 - Characterization of the media used in the degradation test

\begin{tabular}{c|c|c|c}
\hline Parameter & Fresh water & Saline water & Standard \\
\hline $\mathrm{pH}$ & 7.39 & 7.87 & ASTM D4972-01 \\
\hline COD $(\mathrm{mg} / \mathrm{L})$ & 109 & 115 & NBR 10357 \\
\hline BOD $(\mathrm{mg} / \mathrm{L})$ & 20 & 20 & NBR 12614 \\
\hline $\begin{array}{c}\text { Total coliforms } \\
(\mathrm{NMP} / 100 \mathrm{~mL})\end{array}$ & $2.4 \times 10^{3}$ & $4.1 \times 10^{1}$ & APHA 20th Ed \\
\hline $\begin{array}{c}\text { Fecal coliforms } \\
(\mathrm{NMP} / 100 \mathrm{~mL})\end{array}$ & $2.0 \times 10^{2}$ & $\mathrm{ND}$ & APHA 20th Ed \\
\hline Turbidity (NTU) & 55.3 & 1.40 & ABNT MB 3227
\end{tabular}

\subsection{Sample preparation}

The PP blends were prepared with $4 \%$ by weight of additive, one blend of each percentage for each additive (organic and enzymatic). The mixing was carried out in a HAAKE Rheomix mixer by the company Thermo Fisher Scientific located in the Industrial Chemistry Laboratory of the School of Sciences of the Pontifical Catholic University of Rio Grande do Sul State (PUCRS), with the following operational conditions: process temperature of $170^{\circ} \mathrm{C}$, rotation of $60 \mathrm{rpm}$, and time of 7 minutes (Adapted from Mohamad et al., 2013).

The pure PP films as well as the blends films of different additives were prepared in a Marconi hydraulic press, with a capacity of 15 tons, located at the PUCRS School of Sciences. Films with thickness between 0.3 and $0.6 \mathrm{~mm}$ were obtained by pressing between aluminum plates with Teflon at a temperature of $160^{\circ} \mathrm{C}$ and a load of 3 tons for 2 minutes. The nomenclature adopted for the samples is: PP (pure polypropylene), PP-4Enz 
(polypropylene blend with 4\% enzymatic additive), and PP-4Org (polypropylene blend with $4 \%$ organic additive).

\subsection{Degradation tests}

The degradation tests were conducted in order to simulate the conditions in which plastic waste is disposed of in the environment in the most real way possible. To achieve such a goal, two of the main media of disposal of this waste were chosen: fresh water and saline water. All experiments were executed at the Geochemical Analysis Laboratory (LAG) of the Petroleum and Natural Resources Institute (IPR) of PUCRS. All tests were carried out in the same place, on a microprocessed shaking table model Q225M by Quimis under the following conditions: agitation of $50 \mathrm{rpm}$, temperature from 10 to $31^{\circ} \mathrm{C}$, and humidity from 29 to $60 \%$ subject to daily changes. The exposure time of the samples was 6 months. Figure 2 shows the scheme of the conducted experiments.

The methodology used for the degradation test with natural waters (fresh and saline) was adapted from studies available in the literature (Chiellini et al., 2007; Veethahavya et al., 2016). Furthermore, the dimensions of the specimens were $15 \mathrm{~mm} \times 15 \mathrm{~mm}$, and the amount of water for each sample was $15 \mathrm{ml}$. The fresh water used for the degradation test was collected at Guaíba Lake in the city of Guaíba, whereas the saline water used was collected at Pinhal Beach on the coast of Rio Grande do Sul State.

Figure 2 - Degradation test assembly in fresh and saline water
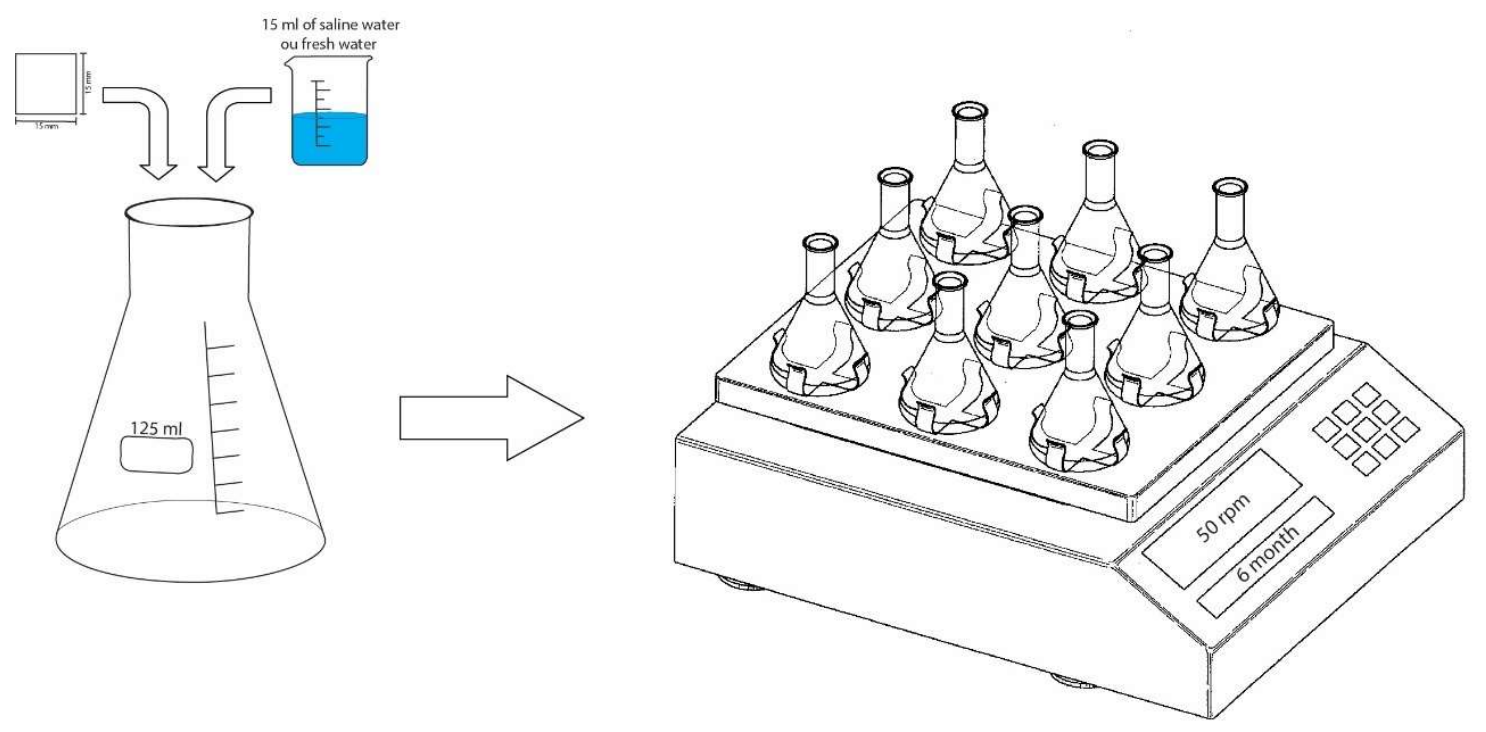


\subsection{Characterizations}

The samples were characterized before and after the degradation tests in order to evaluate their behavior. Moreover, to assess the degree of degradation after the experiments, appropriate techniques were used to determine changes in the chemical and morphological properties of the materials. All analyzes were performed in triplicates. It is also noteworthy that before the analysis, the samples were previously dried.

\section{1) Fourier Transformed Infrared Spectroscopy (FTIR)}

Infrared spectroscopy analyzes were performed in order to evaluate changes in the absorption bands related to the chemical bonds present in the samples, which indicates chemical changes in the sample. For this purpose, a Perkin Elmer Instruments Spectrum One FT-IR Spectrometer was used. The spectrum was acquired with the UATR sample accessory (universal total attenuated reflectance accessory) in the wave number range from 4000 to $650 \mathrm{~cm}^{-1}$. FTIR analyzes were performed in the Spectroscopy laboratory of the School of Sciences at PUCRS. The carbonyl index (COi) was calculated according to the method described in the literature for samples before and after the degradation test (Barbes et al., 2014). COi was calculated through Equation (1).

$$
\mathrm{CO}_{i}=\frac{A_{1715}}{A_{2870}}
$$

Where $A_{1715}$ is the absorbance of the carbonyl group (-CO-) and $A_{2870}$ is the absorbance of the methylene group $\left(-\mathrm{CH}_{2}-\right)$.

\subsection{Field Emission Scanning Electron Microscopy (FESEM)}

Scanning electron microscopy imaging was used to evaluate the morphology of the samples before and after the degradation tests. The images were obtained in FEI Inspect F50 equipment in the mode of secondary electrons (SE) available at the Central Laboratory of Microscopy and Microanalysis (LabCEMM) of PUCRS. It is worth mentioning that the samples were metallized with gold. The images obtained by the SEM analysis displayed in this study for comparison are at the same magnification (20,000 times). 


\section{Results e Discussion}

Scanning electron microscopy imaging was used to evaluate the morphology of the samples before and after the degradation tests. The images were obtained through FEI Inspect F50 equipment in the mode of secondary electrons (SE) available at the Central Laboratory of Microscopy and Microanalysis (LabCEMM) of PUCRS. It is worth mentioning that the samples were metallized with gold. The images obtained by the SEM analysis displayed in this study for comparison are at the same magnification (20,000 times).

The structural characteristics of the samples before and after the degradation test in fresh and saline water were evaluated from the FTIR analysis to verify the changes resulting from their exposure. Figure 3 shows the infrared spectra of the PP (a), PP-4Enz (b) and PP4Org (c) samples in saline water and PP (d), PP-4Enz (e) and PP-4Org (f) in fresh water, with 0 and 180 days of exposure. In fact, it was possible to evaluate changes in the chemical structure of the polymer. Spectra were obtained from all months of the degradation tests, even though for better visualization, only the initial results were presented and after 6 months of exposure.

Figure 3 - Infrared spectra of PP (a), PP-4Enz (b) and PP-4Org (c) samples in saline water and PP (d), PP-4Enz (e), and PP-4Org (f) in fresh water
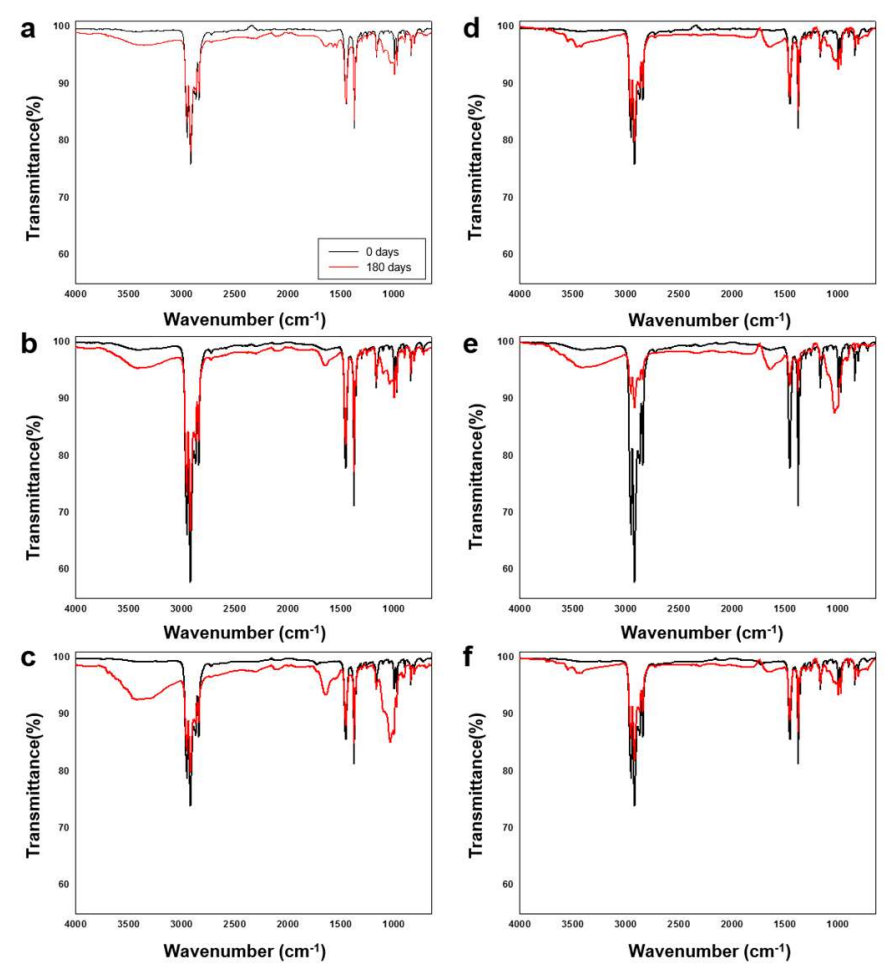
Based the spectra of Figure 3, there is an increase and / or appearance of absorption bands in the region of $3348 \mathrm{~cm}^{-1}$ corresponding to the axial deformation of the $\mathrm{OH}$ group, $1647 \mathrm{~cm}^{-1}$ attributed to the presence of the unsaturated ethylene group $(C=C), 1371 \mathrm{~cm}^{-1}$ to alkyl groups $\left(\mathrm{CH}_{3}\right), 1100-1007 \mathrm{~cm}^{-1}$ to $-\mathrm{CO}$ - alcohol bond and elongation of the NO bond, respectively, and $910 \mathrm{~cm}^{-1}$ to vinyl group $\left(-\mathrm{HC}=\mathrm{CH}_{2}\right)$ (Miyazaki et al., 2012; Peixoto et al., 2017; Auta et al., 2018; Skariyachan et al., 2018).

It is worth mentioning that the band corresponding to the axial deformation of the $-\mathrm{OH}$ group $\left(3348 \mathrm{~cm}^{-1}\right)$ showed a significant increase with the time of fresh water degradation, mainly for mixtures. This can be attributed to the absorption of water due to the presence of polar groups in the composition of the additive (Gulmine et al. 2003; Tavares et al. 2017)

According to Das and Kumar (2015), the band in the $910 \mathrm{~cm}^{-1}$ region may be related to depolymerization caused by microorganisms. Moreover, the carbonyl $(-C=O)$ of the aldehyde and / or ester appeared in the $1730 \mathrm{~cm}^{-1}$ region after 30 days of testing. Albertsson et al. (1995) concluded that the carbonyl groups can be produced by oxidizing agents and are the main factors that indicate the beginning of the degradation, being attacked by microorganisms that degrade the shortest segments of the chains. Along with the literature, the increase in the unsaturated ethylene group causes a decrease in hydrophobicity, facilitating access to microbial degradation (Potts et al., 1973). Comparing the samples, it is possible to observe that the PP-4Enz samples in sea water and PP-4Org in fresh water showed more intense structural changes, mainly in the bands related to the carbonyl and ethylene groups.

Through the infrared spectra, the carbonyl indices (COi) for the samples were obtained (Figure 4). The percentage increase in COi was calculated for the exposure time of 30 days, as it was the highest value found. Based on the literature, an increase in the carbonyl content is expected initially, as it is related to the breakdown of the polymeric chain and, consequently, to the oxidation of PP. After some time of exposure to the media, microorganisms consume these produced compounds and, therefore, there is a decrease in COi (Montagna et al., 2016; Tavares et al., 2017). 
Figure 4 - Carbonyl index for samples in saline water (a) and fresh water (b).
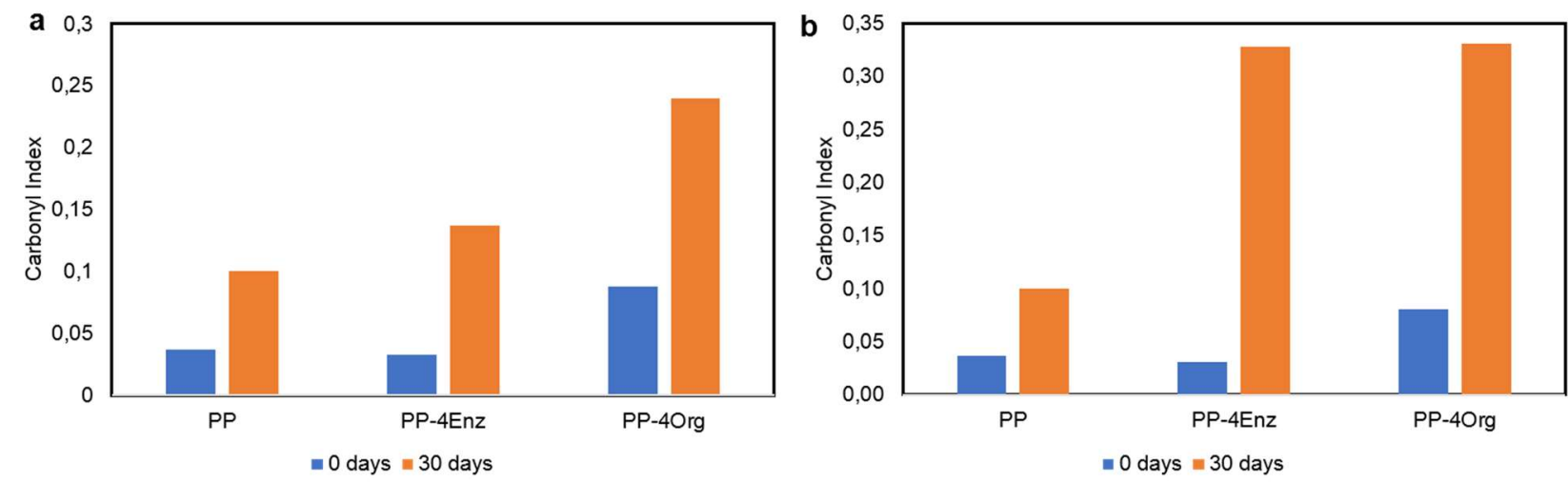

This explains the behavior obtained for the samples, in which an increase was observed after 30 days followed by a decrease in the COi in the next periods. In addition, it is noteworthy that there was a greater variation in the carbonyl index for samples with enzymatic additive for both fresh water ( 415) and saline water ( 1078), with an increase in the carbonyl content much greater in saline water.

The morphologies of the samples before and after the degradation tests are described below. Figure 5 shows the SEM images for the PP samples and for the samples added before the degradation test and after 30,90, and 180 days of exposure in both media.

Figure 5 - SEM images for PP and PP added in both exposure media.

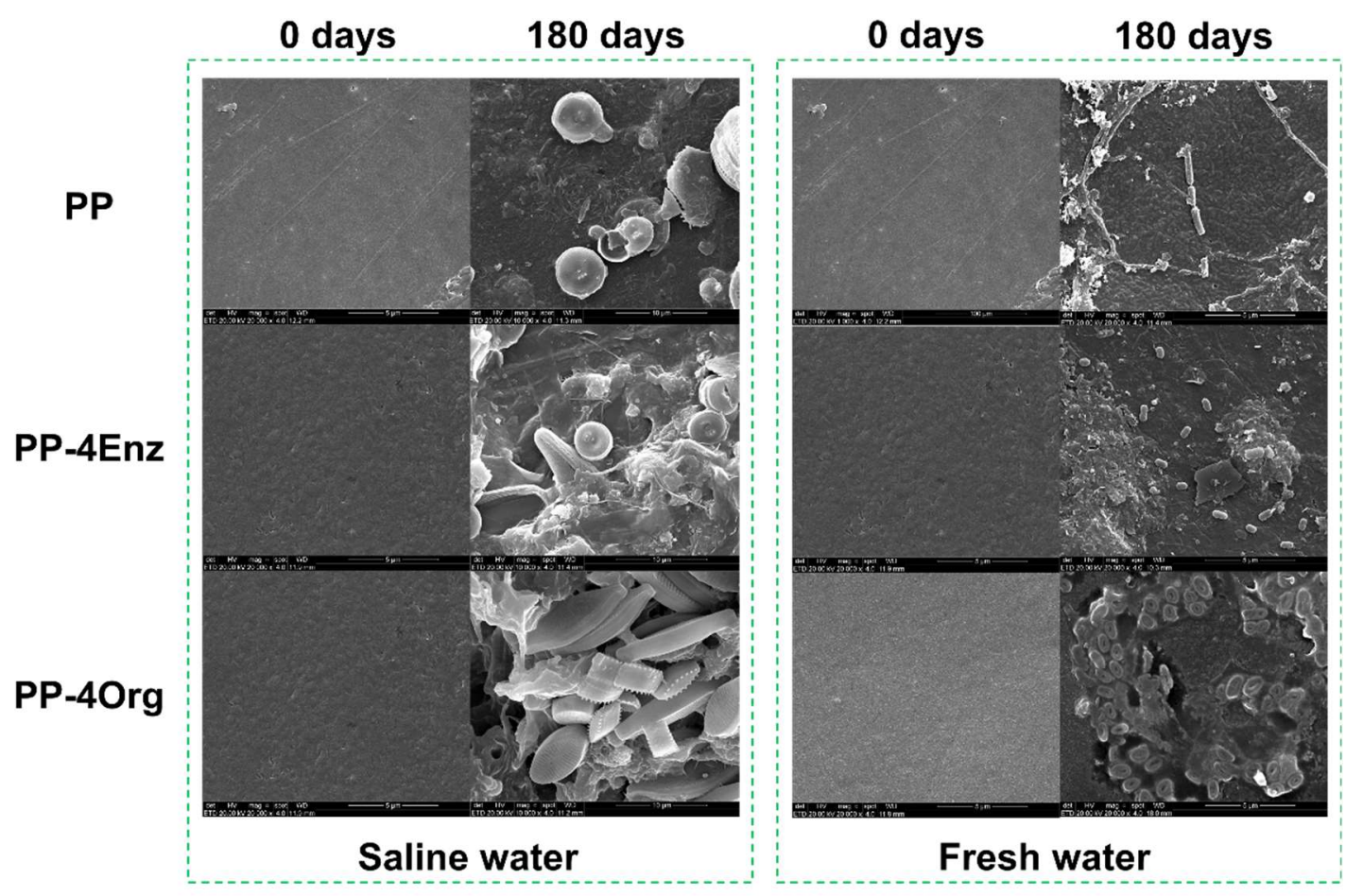


Based on the figure above, it is possible to verify the presence of some microorganisms adhered to the surface of the PP. However, the exposure time had no influence on the amount of microorganisms (MOs) adhered, since even with the passage of days few bacteria have been identified adhered to the surface of the material.

Furthermore, there was biofilm formation in all samples added after exposure to aqueous media. Biofilm, or microfouling, is the process in which a complex community of microorganisms is established on a surface. Biofilms are made up of MOs and their extracellular polysaccharides (Ford, 1993; Fletcher, 1996; Neu, 1996; Gu, 2003). Biodegradation depends on the formation of biofilm, specifically a deposition layer of the microorganism and its secreted polysaccharides on the polymer surface, followed by the breakdown of the polymer into low molecular weight oligomers, probably due to the enzymes secreted by the microbes and then easily assimilated by them (Arkatkar et al., 2009).

At the same time, changes in the surface of the samples were observed, as well as the presence of some bacteria, fungi, and hyphae adhered, as previously described (Matsunaga and Whitney, 2000; Bonhomme et al., 2003; Husarova et al., 2010 ; Sivan, 2011). It is also noteworthy that after 90 days of exposure to sea water, there was colonization of a protist group, the diatoms. Diatoms are unicellular algae organisms that have siliceous structures. These consist mainly of acidic polysaccharides that can be carboxylated and / or sulfated in different levels. Diatoms present in marine environments colonize the surfaces of the polymers existing in that environment, especially where there are rough surfaces (Carson et al., 2013; Pelegrini et al., 2016). Wahl (1989) carried out studies in the area, where it was evidenced that, in general, bacterial colonization precedes and facilitates colonization by diatoms. Therefore, it is understood that the presence of bacteria on the surface of the blends attracted and favored the adhesion of the diatoms.

\section{Final considerations}

The results obtained in this study showed that incorporation of the additives into the polymeric matrix caused major changes in the properties evaluated in relation to pure PP. 
Thus, it was possible to conclude that the presence of the additives interfered in the structural characteristics (appearance of oxygenated groups and double bonds that indicate the occurrence of the degradation process) and in the morphology (presence of microorganisms adhered to the material surface), favoring the degradation process of the material.

Furthermore, it was concluded that exposure to degradation media (saline and fresh water) facilitated microbial attack, and with increased exposure time, there were more marked changes in the properties of the materials. At the same time, it was observed that saline water was more aggressive to the materials, causing greater changes.

Thus, taking into account all the aspects discussed, it can be concluded that the incorporation of commercial additives attributes biodegradable characteristics to PP. It is also worth mentioning that further research is necessary to better understand the influence of these materials.

Finally, this study has an important role in the research and development of biodegradable materials in order to minimize the effects caused by plastic waste in the environment.

\section{Acknowledgments}

The authors would like to thank the Pontifical Catholic University of Rio Grande do Sul State for the support received. The present work was done with the support of Coordination of Improvement of Higher Level Personnel - Brazil (CAPES) - Finance Code 001, and Brasilata Company.

\section{References}

ABIPLAST. Perfil 2015: Indústria Brasileira de Transformação de Material Plástico. Associação Brasileira da Indústria do Plástico, 2015. Available in: <http://file.abiplast.org.br/download/2016/perfil_2015_ok.pdf>

ABIPLAST. Preview perfil 2016, 2016. Available in: <http://file.abiplast.org.br/file/noticia/2017/folder_preview_perfil2016_separado.pdf> 
ABRE. Consumo de resinas plásticas cresce no brasil em 2017, 2018. Available in: <http://www.abre.org.br/noticias/consumo-de-resinas-plasticas-cresce-no-brasil-em2017/>

ACHILIAS, D. S.; ROUPAKIAS, C. P.; MEGALOKONOMOS, A.A.; LAPPAS, E. V.; ANTONAKOU. Chemical recycling of plastic wastes made from polyethylene (LDPE and HDPE) and polypropylene (PP). Journal of Hazardous Materials, v. 149, n. 3, p. 536-542, 2007.

ALBERTSSON, A. C.; BARENSTEDT, C.; KARLSSON, S.; LINDBERG, T. Degradation product pattern and morphology changes as means to differentiate abiotically and biotically aged degradable polyethylene. Polymer, v. 36, n. 16, p. 3075-3083, 1995.

AMERICAN SOCIETY FOR TESTING AND MATERIALS. Standard Test Method for $\mathrm{pH}$ of Soils, ASTM D4972-01. United States of America, 2001.

ARKATKAR, A.; ARUTCHELVI, J.; SUDHAKAR, M.; BHADURI, S.; UPPARA, P. V.; DOBLE, M. Approaches to enhance the biodegradation of polyolefins. The Open Environmental Engineering Journal, v. 2, n. 1, 2009.

ASSOCIAÇÃO BRASILEIRA DE NORMAS TÉCNICAS. Águas - Determinação da Demanda Bioquímica de Oxigênio (DBO) - Método de Incubação $\left(20^{\circ} \mathrm{C}\right.$, cinco dias), NBR -12614. Rio de Janeiro, 1992.

ASSOCIAÇÃO BRASILEIRA DE NORMAS TÉCNICAS. Águas - Determinação da Demanda Química de Oxigênio (DQO) - Método do Refluxo Aberto e Titulométrico, NBR - 10357. Rio de Janeiro, 1988.

ASSOCIAÇÃO BRASILEIRA DE NORMAS TÉCNICAS. Águas Minerais e de Mesa Determinação de Turbidez - Método Nefelométrico, ABNT MB - 3227. Rio de Janeiro, 1990.

AUTA, H. S.; EMENIKE, C. U.; JAYANTHI, B.; FAUZIAH, S. H. Growth kinetics and biodeterioration of polypropylene microplastics by Bacillus sp. and Rhodococcus sp. isolated from mangrove sediment. Marine Pollution Bulletin, v. 127, p. 15-21, 2018.

BARBES, L.; RADULESCU, C.; STIHI, C. ATR-FTIR spectrometry characterisation of polymeric materials. Romanian Reports in Physics, v. 66, n. 3, p. 765-777, 2014.

BOHLMANN, G. M. General Characteristics, Processabily, Industrial Applications and Market Evolution of Biodegradable Polymers. In: Handbook of Biodegradable Polymers. Shrospire: Rapra Techonology, 2005, Cap. 6, p. 183-218.

CARSON, H. S.; NERHEIM, M. S.; CARROLL, K. A.; ERIKSEN, M. The plastic-associated microorganisms of the North Pacific Gyre. Marine pollution bulletin, v. 75, n. 1-2, p. 126132, 2013. 
CHIELLINI, E.; CORTI, A.; D'ANTONE, S. Oxo-biodegradable full carbon backbone polymersbiodegradation behaviour of thermally oxidized polyethylene in an aqueous medium. Polymer Degradation and Stability, v. 92, n. 7, p. 1378-1383, 2007.

DAS, M. P.; KUMAR, S. An approach to low-density polyethylene biodegradation by Bacillus amyloliquefaciens. 3 Biotech, v. 5, n. 1, p. 81-86, 2015.

FARIA, A. U.; MARTINS-FRANCHETTI, S. M. Biodegradação de filmes de polipropileno (PP), poli (3-hidroxibutirato) (PHB) e blenda de PP/PHB por micro-organismos das águas do Rio Atibaia. Polímeros, v. 20, n. 2, p. 141-147, 2010.

FLETCHER, M. Diversity of surfaces and adhesion strategies. Bacterial adhesion: molecular and ecological diversity, v. 19, n. 1, 1996.

FONTANELLA, S.; BONHOMME, S.; BRUSSON, J. M.; PITTERI, S.; SAMUEL, G.; PICHON, G.; LACOSTE, J.; FROMAGEOT, D.; LEMAIRE, J.; DELORT, A. M Comparison of biodegradability of various polypropylene films containing pro-oxidant additives based on $\mathrm{Mn}, \mathrm{Mn} / \mathrm{Fe}$ or Co. Polymer degradation and stability, v. 98, n. 4, p. 875-884, 2013.

FORD, T. E. The microbial ecology of water distribution and outfall systems. Aquatic Microbioloqy: An ecoloqical approach. 1993.

GU, J. Microbiological deterioration and degradation of synthetic polymeric materials: recent research advances. International biodeterioration $\boldsymbol{\&}$ biodegradation, v. 52, n. 2, p. 69-91, 2003.

GULMINE, J. V.; JANISSEK, P. R.; HEISE, H. M.; AKCELRUD, L. Degradation profile of polyethylene after artificial accelerated weathering. Polymer degradation and stability, $v$. 79, n. 3, p. 385-397, 2003.

HUSAROVA, L.; MACHOVSKY, M.; GERYCH, P.; HOUSER, J.; KOUTNY, M. Aerobic biodegradation of calcium carbonate filled polyethylene film containing pro-oxidant additives. Polymer Degradation and Stability, v. 95, n. 9, p. 1794-1799, 2010.

LAZAREVIC, D.; AOUSTINA, E.; BUCLET, N.; BRANDT, N. Plastic waste management in the context of a European recycling society: Comparing results and uncertainties in a life cycle perspective. Resources, Conservation and Recycling, v. 55, p. 246-259, 2010.

LIU, X.; GAO, C.; SANGWAN, P.; YU, L.; TONG, Z. Accelerating the degradation of polyolefins through additives and blending. Journal of Applied Polymer Science, v. 131, n. 18, 2014.

MATSUNAGA, M.; WHITNEY, P. J. Surface changes brought about by corona discharge treatment of polyethylene film and the effect on subsequent microbial colonisation. Polymer Degradation and Stability, v. 70, n. 3, p. 325-332, 2000. 
MIYAZAKI, K.; ARAI, T.; SHIBATA, K.; TERANO, M.; NAKATANI, H. Study on biodegradation mechanism of novel oxo-biodegradable polypropylenes in an aqueous medium. Polymer degradation and stability, v. 97, n. 11, p. 2177-2184, 2012.

MOHAMAD, N.; ZAINOL, N. S.; RAHIM, F. F.; AB MAULOD, H. E.; RAHIM, T. A.; SHAMSURI, S. R.; AZAM, M. A.; YAAKUB, M. Y.; ABDOLLAH, M. F. B.; MANAF, M. E. A. Mechanical and morphological properties of polypropylene/epoxidized natural rubber blends at various mixing ratio. Procedia Engineering, v. 68, p. 439-445, 2013.

MONTAGNA, L. S.; FORTE, M. M. C.; SANTANA, R. M. C. Induced degradation of polypropylene with an organic pro-degradant additive. Journal of Materials Science and Engineering. A, v. 3, n. 2A, p. 123, 2013.

NEU, T. R. Significance of bacterial surface-active compounds in interaction of bacteria with interfaces. Microbiological reviews, v. 60, n. 1, p. 151, 1996.

OJEDA, T. F. M. Biodegradabilidade de materiais poliméricos. Rio Grande do Sul. 2008. 128 p. Tese de Doutorado - Faculdade de Agronomia, Universidade Federal do Rio Grande do Sul, Brasil.

PEIXOTO, J.; SILVA, L. P.; KRUGER, R. H. Brazilian Cerrado soil reveals an untapped microbial potential for unpretreated polyethylene biodegradation. Journal of Hazardous Materials, v. 324, p. 634-644, 2017.

PELEGRINI, K.; DONAZZOLO, I.; BRAMBILLA, V.; GRISA, A. M. C.; PIAZZA, D.; ZATTERA, A. J.; BRANDALISE, R. N. Degradation of PLA and PLA in composites with triacetin and buriti fiber after 600 days in a simulated marine environment. Journal of Applied Polymer Science, $v$. 133, n. 15, 2016.

PIATTI, T. M.; RODRIGUES, R. A. F. Plásticos: características, usos, produção e impactos ambientais. Maceió: Edufal, 2005, 51 p

PLASTIC EUROPE. PlasticsEurope Annual Review 2017-2018. Brussels: Association of Plastic Manufacturers, 2018, 44 p.

POTTS, J. E.; CLENDINING, R. A.; ACKART, W. B.; NIEGISCH, W. D. In Polymer Science and Technology; Guillet, J., Ed. 1973.

ROSA, D. S.; PENTEADO, D. F.; CALIL, M. R. Propriedades Térmicas e Biodegradabilidade de PCL e PHB em um Pool de Fungos. Polímeros: Ciência e Tecnologia, v. 15, p. 75-80, jun. 2000.

SIVAN, A. New perspectives in plastic biodegradation. Current opinion in biotechnology, v. 22, n. 3, p. 422-426, 2011.

SKARIYACHAN, S.; PATIL, A. A.; SHANKAR, A.; MANJUNATH, M.; BACHAPPANAVAR, N.; KIRAN, S. Enhanced polymer degradation of polyethylene and polypropylene by novel 
thermophilic consortia of Brevibacillus sps. and Aneurinibacillus sp. screened from waste management landfills and sewage treatment plants. Polymer Degradation and Stability, v. 149, p. 52-68, 2018.

TAVARES, L. B.; ROCHA, R. G.; ROSA, D. S. An organic bioactive pro-oxidant behavior in thermal degradation kinetics of polypropylene films. Iranian Polymer Journal, v. 26, n. 4, p. 273-280, 2017.

THOMAS, N. L.; CLARKE, J.; MCLAUCHLIN, A. R.; PATRICK, S. G. Oxo-degradable plastics: degradation, environmental impact and recycling. Proceedings of the Institution of Civil Engineers: Waste and Resource Management, v. 165, n. 3, p. 133-140, 2012.

VEETHAHAVYA, K. S.; RAJATH, B. S.; NOOBIA, S.; KUMAR, B. M. Biodegradation of Low Density Polyethylene in Aqueous Media. Procedia Environmental Sciences, v. 35, p. 709713, 2016.

WAHL, M. Marine epibiosis. I. Fouling and antifouling: some basic aspects. Marine ecology progress series, v. 58, p. 175-189, 1989.

ZANIN, M.; MANCINI, S. D. Resíduos plásticos e reciclagem: aspectos gerais e tecnologia. $2^{\circ}$ Ed. São Carlos: SciELO Books, 2015, 138 p. 